\title{
The Effectiveness of Scientific Argumentation Strategy towards the Various Learning Outcomes and Educational Levels Five Over the Years in Science Education
}

\author{
Indah Juwita Sari ${ }^{13 *}$, R. Ahmad Zaky El Islami2,3 \\ ${ }^{1}$ Department of Biology Education, Faculty of Teacher Training and Education, Universitas Sultan Ageng Tirtayasa, Indonesia \\ ${ }^{2}$ Department of Science Education, Faculty of Teacher Training and Education, Universitas Sultan Ageng Tirtayasa, Indonesia \\ ${ }^{3}$ Division of Science Education, Faculty of Education, Kasetsart University, Thailand
}

*Correspondence to: indah.sa@ku.th

\begin{abstract}
This study aimed to investigate the effectiveness of scientific argumentation strategy towards various learning outcomes and educational levels five over the years in science education. This study was used systematic review and meta-analysis using $R$ application. Selected ten articles from the Web of Science database during 2016-2020 were used in this study. The results showed that scientific reasoning is more effective for improving through scientific argumentation in the higher education level than other learning outcomes and other educational levels with an effect size 1.39 and standard error 0.2478 . So, we can conclude that there is evidence to suggest using a scientific argumentation strategy in improving scientific reasoning in higher education levels both in the teaching process and the research.
\end{abstract}

Keywords: Scientific Argumentation; Scientific Reasoning; Systematic Review; Meta-Analysis; Science Education

Recommended citation: Sari, I. J., \& Islami, R. A. Z. E. (2020). The Effectiveness of Scientific Argumentation Strategy towards the Various Learn-ing Outcomes and Educational Levels Five Over the Years in Science Education. Journal of Innovation in Educational and Cultural Research, 1(2), 52-57

\section{INTRODUCTION}

Scientific argumentation plays an important role in science that tries to validate a claim on the primary reasons in a manner that reflect the values in the community of science (Norris et al., 2007). Scientific argumentation is a logical and rational discourse aimed at finding the relationship between ideas and evidence (Duschl et al., 2007). Sampson \& Schleigh (2013) state that there are three scientific argumentation components, including the claim, the evidence, and justification of the evidence. The claim is about explaining to answer the research question. The evidence is activity to interpret the results of observing, measuring, or looking for other studies. A justification of the evidence is explaining the relevant or rational evidence and linking it to a specific concept (Sampson \& Schleigh, 2013). Scientific argumentation in science education has many advantages, such as stimulating students' motivation, promoting conceptual understanding, enhancing the performance of students, and developing critical thinking (Faize et al., 2007).

Today, scientific argumentation is a pedagogical practice and core competency in school science in many countries (Giri \& Pailiy, 2020). Program for International Student Assessment (PISA) encourages the ability to use scientific evidence to support the claims as necessary in scientific argumentation components (OECD, 2013). The National Research Council (2012) identified engaging in argument from evidence as one of the eight essential scientific practices students should experience in K-12 science education. The European Union officially recommended incorporating scientific argumentation as a set of critical competencies for lifelong learning (European Union, 2006). Tsai (2018) found that the socio-scientific issue scientific argumentation strategy involves diverse responses, explanations, and challenging opposite views with countering ideas.

The scientific argumentation definition by Norris et al. (2007) and Sampson \& Schleigh (2013) is defined as a strategy. Norris et al. (2007) define scientific argumentation as an attempt to validate or refute a claim using reasons in a manner that reflects the values of the scientific community. Similar to Norris et al. (2007), the definition of scientific argumentation by Sampson \& Schleigh (2013) was adopted from Norris et al. (2017).

A previous study on scientific argumentation by Engelmann et al. (2016) showed that scientific argumentation is one of the successful strategies to enhance scientific reasoning. However, this previous study has conducted a meta-analysis on scientific reasoning to investigate the suitable strategy which successfully implemented in improving scientific reasoning at the school level. So, we need to investigate the effectiveness of 
scientific argumentation strategy towards various learning outcomes in science education in various education levels.

Based on the previous studies, this study aimed to investigate the effectiveness of scientific argumentation strategy towards the various learning outcomes and educational levels in science education using systematic review and meta-analysis. This study would provide educational researchers with a deeper understanding of the learning outcomes that can be improved effectively through scientific argumentation at various educational levels.

\section{METHOD}

This study was used systematic review and meta-analysis. This study's steps were adapted to the systematic review steps by Dixon-Woods et al. (2006) and Meta-analysis by Lipsey and Wilson (2001). First, we reviewed and decided the research questions "what is the most effective learning outcome to be improved through scientific argumentation strategy?" and "what is the most effective educational level to improve that learning outcome during five years in science education?". Second, we conducted systematic literature to find articles five over the years from 2016 until 2020 in the Web of Science database through the term "scientific argumentation" and found 669 papers. Third, we used the following criteria to select the articles included in the meta-analysis: (a) The paper was an empirical publication in a scientific journal; (b) English language of publication; (c) The paper was included a report of intervention, and at least one between-group comparison in a post-test measuring scientific argumentation; (d) The interventions were conducted in junior high school, high school, and undergraduate level. From the third step, we got ten selected articles that consist of 16 various learning outcomes which be developed through scientific argumentation strategy. Then, we conducted the metaanalysis using the R application.

\section{Data Collection}

The ten selected articles were selected in the web of science database used the term "scientific argumentation." The first step was to use the web of science database by limiting the research articles published in the year 2016-2020 at http://apps.webofknowledge.com.portal.lib.ku.ac.th/Search.do?product=WOS\&SID=E4m 3kceOOJksDy1cqse\&search_mode=GeneralSearch\&prID=7eef81e0-aa51-4c96-ad99-0ef9bc4ff4e3. In this step was found 669 articles during 2016-2020. Then, selected ten articles from 669 articles according to the criteria: (a) The paper was an empirical publication in a scientific journal; (b) English language of publication; (c) The paper was included a report of intervention and at least one between-group comparison in a post-test measuring scientific argumentation; (d) The interventions were conducted in junior high school, high school, and undergraduate level.

\section{Data Analysis}

The meta-analysis in this study used $\mathrm{R}$ application. This meta-analysis used mean and standard deviation from control and experiment groups of 16 learning outcomes from ten research articles. In this step, we got the effect size of all studies and heterogeneity. The categorization of effect size in this study used Cohen (1988) that categorized the effect size to three categorizes; small (Effect Size $\leq .2$ ), medium (Effect Size $\leq .5$ ), and large (Effect Size $\geq .8$ ).

\section{RESULTS AND DISCUSSION}

We have analyzed the comparison of the level group, learning outcome, and the teaching method on scientific argumentation strategy (Table 1). Table 1 shows two learning outcomes in the elementary school level that can be improved through scientific argumentation strategy (Larrain et al., 2018) and two learning outcomes in the junior high school level (Pekel, 2019; Larrain et al., 2019). Meanwhile, in senior high school level, there are six learning outcomes (Tsai, 2018; Ping et al., 2019; Giri \& Paily, 2020), and six learning outcomes in higher education level (Acar \& Patton, 2016; Fan et al., 2020; Faize \& Akhtar, 2020). Based on the systematic review, higher education and senior high school levels are the most educational level studied on various learning outcomes through the scientific argumentation strategy. The example in the previous study in higher education by Fan et al. (2020) was developed online argumentation model for undergraduate students to get proficient in critiquing arguments, defending claims in reasoned discussions with peers, presenting high-quality argumentation, and linking science education and daily experiences in the instructional argumentation process for improved learning. The example in the previous study in senior high school by Tsai (2018) was integrated the socio-scientific issue in the scientific argumentation strategy in senior high school. Sadler and Zeidler $(2005 a ; b)$ state that students need to support their arguments using scientific evidence. So, it can be the reason why scientific argumentation can be implemented in senior high school. 
We divided learning outcomes into three types through scientific argumentation, including knowledge, skills, and attitude (Gagne, 1984). Gagne (1984) and Bloom (1956) state that knowledge, skill, and attitude are the learning outcomes that have been distinguished and appear to be widely accepted. Table 1 shows that 11 learning outcomes in the knowledge domain can be improved through scientific argumentation strategy (Acar \& Patton, 2016; Tsai, 2018; Pekel, 2019; Larrain et al., 2018; Fan et al., 2020; Faize \& Akhtar, 2020; Larrain et al., 2019; Giri \& Paily, 2020), three learning outcomes in skill domain (Larrain et al., 2018; Ping et al., 2019), and two learning outcomes in attitude domain (Tsai, 2018; Faize \& Akhtar, 2020). Based on the systematic review, the learning outcome in the knowledge domain is the most learning outcome which is developed through scientific argumentation. All educational levels in these previous studies assess the learning outcome in the knowledge domain. Tsai (2018) assessed students' scientific competencies as one of the scientific knowledge to identify questions and to draw evidence-based conclusions using online argumentation of socio-scientific issues.

Table 1. Comparison of the educational level, learning outcome, and the teaching method on scientific argumentation strategy

\begin{tabular}{|c|c|c|c|}
\hline Reference & $\begin{array}{l}\text { Educational } \\
\text { Level }\end{array}$ & Learning outcome & Teaching method on scientific argumentation strategy \\
\hline $\begin{array}{l}\text { Acar \& Patton } \\
(2016)\end{array}$ & $\begin{array}{l}\text { Higher } \\
\text { education }\end{array}$ & $\begin{array}{l}\text { Knowledge } \\
\text { achievement }\end{array}$ & Argumentation-Based Inquiry \\
\hline $\begin{array}{l}\text { Acar \& Patton } \\
(2016)\end{array}$ & $\begin{array}{l}\text { Higher } \\
\text { education }\end{array}$ & Scientific reasoning & Argumentation-Based Inquiry \\
\hline Tsai (2018) & $\begin{array}{l}\text { Senior high } \\
\text { school }\end{array}$ & $\begin{array}{l}\text { Scientific } \\
\text { competencies }\end{array}$ & $\begin{array}{l}\text { Socio-scientific issues Online-Argumentation Pattern } \\
\text { (SOAP) }\end{array}$ \\
\hline Tsai (2018) & $\begin{array}{l}\text { Senior high } \\
\text { school }\end{array}$ & $\begin{array}{l}\text { Sustainability } \\
\text { attitudes }\end{array}$ & $\begin{array}{l}\text { Socio-scientific issues Online-Argumentation Pattern } \\
\text { (SOAP) }\end{array}$ \\
\hline $\begin{array}{l}\text { Larrain et al. } \\
\text { (2018) }\end{array}$ & $\begin{array}{l}\text { Elementary } \\
\text { school }\end{array}$ & $\begin{array}{l}\text { Disciplinary content } \\
\text { knowledge }\end{array}$ & Peer-Group Argumentative Dialogue \\
\hline $\begin{array}{l}\text { Larrain et al. } \\
\text { (2018) }\end{array}$ & $\begin{array}{l}\text { Elementary } \\
\text { school }\end{array}$ & $\begin{array}{l}\text { Individual } \\
\text { argumentation skills }\end{array}$ & Peer-Group Argumentative Dialogue \\
\hline Pekel (2019) & $\begin{array}{l}\text { Junior high } \\
\text { school }\end{array}$ & $\begin{array}{l}\text { Students' } \\
\text { understanding }\end{array}$ & Argumentation-based concept cartoons \\
\hline $\begin{array}{l}\text { Ping et al. } \\
\text { (2019) }\end{array}$ & $\begin{array}{l}\text { Senior high } \\
\text { school }\end{array}$ & $\begin{array}{l}\text { Science Process } \\
\text { Skills }\end{array}$ & Modified Argument-Driven Inquiry (MADI) Strategy \\
\hline $\begin{array}{l}\text { Ping et al. } \\
\text { (2019) }\end{array}$ & $\begin{array}{l}\text { Senior high } \\
\text { school }\end{array}$ & Practical Skills & Modified Argument-Driven Inquiry (MADI) Strategy \\
\hline $\begin{array}{l}\text { Ping et al. } \\
\text { (2019) }\end{array}$ & $\begin{array}{l}\text { Senior high } \\
\text { school }\end{array}$ & $\begin{array}{l}\text { Experimental } \\
\text { Planning }\end{array}$ & Modified Argument-Driven Inquiry (MADI) Strategy \\
\hline $\begin{array}{l}\text { Larrain et al. } \\
\text { (2019) }\end{array}$ & $\begin{array}{l}\text { Junior high } \\
\text { school }\end{array}$ & $\begin{array}{l}\text { Science content } \\
\text { knowledge }\end{array}$ & Peer argumentation \\
\hline $\begin{array}{l}\text { Fan et al. } \\
(2020)\end{array}$ & $\begin{array}{l}\text { Higher } \\
\text { education }\end{array}$ & $\begin{array}{l}\text { students' } \\
\text { argumentation ability }\end{array}$ & Online argumentation model \\
\hline $\begin{array}{l}\text { Fan et al. } \\
(2020)\end{array}$ & $\begin{array}{l}\text { Higher } \\
\text { education }\end{array}$ & $\begin{array}{l}\text { Knowledge } \\
\text { achievement }\end{array}$ & Online argumentation model \\
\hline $\begin{array}{l}\text { Faize \& Akhtar } \\
\text { (2020) }\end{array}$ & $\begin{array}{l}\text { Higher } \\
\text { education }\end{array}$ & $\begin{array}{l}\text { Environmental } \\
\text { knowledge }\end{array}$ & Scientific argumentation strategy \\
\hline $\begin{array}{l}\text { Faize \& Akhtar } \\
\text { (2020) }\end{array}$ & $\begin{array}{l}\text { Higher } \\
\text { education }\end{array}$ & $\begin{array}{l}\text { Environmental } \\
\text { attitude }\end{array}$ & Scientific argumentation strategy \\
\hline $\begin{array}{l}\text { Giri \& Paily } \\
(2020)\end{array}$ & $\begin{array}{l}\text { Senior high } \\
\text { school }\end{array}$ & Critical thinking & $\begin{array}{l}\text { Toulmin's argument pattern (TAP) within Think-Read- } \\
\text { Group-Share-Reflect (TRGSR) scientific argumentation } \\
\text { strategy }\end{array}$ \\
\hline
\end{tabular}

Additionally, Pekel (2019) examined the effectiveness of argumentation-based concept cartoons on students' understanding of global warming, ozone layer depletion, and acid rain, compared to a traditional teaching Strategy. Dawson and Venville (2013) stated that one of the aims of international science education is to develop a deeper understanding of students on the world around them and they could use the understanding of science to contribute to public debate and make informed and balanced decisions about scientific issues that impact their lives. Jimenez-Aleixandre \& Erduran (2008) state that scientific argumentation strategy as scientific learning is to develop a scientific way of thinking that is characterized by question-driven processes of inquiry 
about social and natural phenomena, in which evidence is gathered and alternative interpretations evaluated through a rational process that unfolds in the discourse, leading to knowledge construction and conceptual understanding

\begin{tabular}{|c|c|c|c|c|c|c|}
\hline Study & TE seTE & $\begin{array}{l}\text { Standardised Mear } \\
\text { Difference }\end{array}$ & & SMD & $95 \%-\mathrm{Cl}$ & Weight \\
\hline Acar \& Patton (2016) & 0.010 .2234 & +1 & & 0.01 & {$[-0.43 ; 0.44]$} & $6.4 \%$ \\
\hline Acar \& Patton (2016) & 1.390 .2478 & $\mp$ & & 1.39 & {$[0.90 ; 1.87]$} & $5.2 \%$ \\
\hline Tsai (2018) & 0.010 .1817 & + & & 0.01 & {$[-0.35 ; 0.37]$} & $9.7 \%$ \\
\hline Tsai (2018) & 0.600 .2488 & $\doteqdot$ & & 0.60 & {$[0.11 ; 1.08]$} & $5.2 \%$ \\
\hline Larrain et al (2018) & 0.610 .2640 & $\therefore$ & & 0.61 & {$[0.09 ; 1.12]$} & $4.6 \%$ \\
\hline Larrain et al (2018) & -0.900 .2943 & 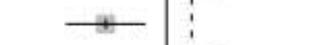 & & -0.90 & {$[-1.47 ;-0.32]$} & $3.7 \%$ \\
\hline Pekel (2019) & 0.750 .3018 & $i$ & & 0.75 & {$[0.16 ; 1.34]$} & $3.5 \%$ \\
\hline Ping et al (2019) & $0.65 \quad 0.2452$ & ॠ & & 0.65 & {$[0.17 ; 1.13]$} & $5.3 \%$ \\
\hline Ping et al (2019) & $0.56 \quad 0.2435$ & $\div$ & & 0.56 & {$[0.08 ; 1.03]$} & $5.4 \%$ \\
\hline Ping et al (2019) & -0.470 .2423 & $\mp \vdots$ & & -0.47 & {$[-0.95 ; 0.00]$} & $5.4 \%$ \\
\hline Fan et al (2020) & $0.47 \quad 0.1775$ & $\div$ & & 0.47 & {$[0.12 ; 0.82]$} & $10.1 \%$ \\
\hline Fan et al (2020) & 0.580 .1786 & + & & 0.58 & {$[0.23 ; 0.93]$} & $10.0 \%$ \\
\hline Faize \& Akhtar (2020) & $1.00 \quad 0.2486$ & - & & 1.00 & {$[0.51 ; 1.48]$} & $5.2 \%$ \\
\hline Faize \& Akhtar (2020) & 0.520 .2385 & 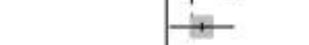 & & 0.52 & {$[0.05 ; 0.99]$} & $5.6 \%$ \\
\hline Giri \& Paily (2020) & 2.690 .3903 & _- & $\longrightarrow$ & 2.69 & {$[1.92 ; 3.45]$} & $2.1 \%$ \\
\hline Larrain et al (2019) & -0.300 .1584 & +1 & & -0.30 & {$[-0.61 ; 0.01]$} & $12.7 \%$ \\
\hline \multirow{2}{*}{\multicolumn{2}{|c|}{ Fixed effect model }} & $\dot{0}$ & & \multirow[t]{4}{*}{0.37} & {$[0.26 ; 0.48]$} & $100.0 \%$ \\
\hline & & & & & {$[-0.86 ; 1.82]$} & \\
\hline \multicolumn{2}{|c|}{ Heterogeneity: $I^{2}=88 \%, \tau^{2}=0.3644, p<0.01$} & 11 & $T$ & & & \\
\hline & -3 & $\begin{array}{lll}-2 & -1 & 0\end{array}$ & 23 & & & \\
\hline
\end{tabular}

Figure 1. Meta-analysis result of scientific argumentation strategy on various learning outcomes and educational levels

Figure 1 shows that the pooled effect size of 16 learning outcomes which improved through scientific argumentation strategy in various education levels is medium level (SMD = 2.37) (Cohen, 1988). It means that all learning outcomes include knowledge, skills, and attitude that can be improved through scientific argumentation. Figure 1 shows that the study from Giri and Paily (2020) has the highest pooled effect size (SMD $=2.69)$ in this meta-analysis study that assessed students' critical thinking in senior high school using Toulmin's argument pattern (TAP) within Think-Read-Group-Share-Reflect (TRGSR) scientific argumentation strategy. However, the study has the highest error (seTE $=0.3903$ ) in this meta-analysis study. That is because the mean of the experimental group has a high gap with the control group's mean if we compare it with the studies in this metaanalysis. According to Hunter dan Schmidt (1990), there are two limitations in a meta-analysis study: sampling error and error of measurement. The most effective learning outcome improved through scientific argumentation strategy is scientific reasoning in higher education level by Acar \& Patton (2016) with an effect size 1.39 and standard error 0.2478. Engelmann et al. (2016) state that scientific reasoning and scientific argumentation use evidence and communicates and scrutinizes the results of a scientific discovery process, and Lawson (2010) states that argumentation and scientific reasoning have a relationship with each other.

Additionally, D'Souza (2018) states that the argumentation strategy is the practice in a science activity that can enhance the epistemic foundation to evaluate good evidence and develop the reason and determine the theories. So, it can be the reason why scientific reasoning is the more effective learning outcome that is developed through scientific argumentation. Additionally, Acar \& Patton (2016) studied in the higher education level. So, we can conclude that scientific reasoning is more useful to be improved through scientific argumentation strategy in the higher education level than other learning outcomes and other educational levels.

\section{CONCLUSION}

The scientific reasoning is more effective for improving through scientific argumentation in higher education than other learning outcomes and other educational levels with an effect size 1.39 and standard error 0.2478 . So, we can conclude that there is evidence to suggest using a scientific argumentation strategy in improving scientific reasoning in higher education levels both in the teaching process and the research. 


\section{REFERENCES}

Acar, Ö., \& Patton, B. R. (2016). Examination of Learning Equity among Prospective Science Teachers Who are Concrete, Formal and Postformal Reasoners after an Argumentation-Based Inquiry Course. Australian Journal of Teacher Education, 41(2).

Bloom, B. S. (1956). Taxonomy of Educational Objectives. Handbook The Cognitive Domain. David McKay, New York.

Cohen, J. (1988). Statistical power analysis for the behavioral sciences (2nd edition). Hillsdale, NJ: Erlbaum.

D'Souza, A. N. (2018). Enhancing and evaluating scientific argumentation in the inquiry oriented college chemistry classroom. Dissertation Abstracts International Section A: Humanities and Social Sciences.

Dawson, V., \& Venville, G. (2013). Introducing high school biology students to argumentation about socioscientific issues. Canadian Journal of Science, Mathematics and Technology Education, 13(4), 356-372.

Duschl, R. A., Scweingruber, H. A., \& Shouse, A. W. (2007). Taking Science to School: learning and teaching science in Grades K-8. Washington, DC: National Academies Press

Dixon-Woods, M., Bonas, S., Booth, A., Jones, D. R., Miller, T., Shaw, R. L., ... Young, B. (2006). How can systematic reviews incorporate qualitative research? A critical perspective. Qualitative Research, 6(1), 27-44.

Engelmann, K., Neuhaus, B. J., \& Fischer, F. (2016). Fostering scientific reasoning in education - meta-analytic evidence from intervention studies. Educational Research and Evaluation, 22(5-6), 333-349.

European Union. (2006). Recommendation of the European Parliament on key competences for lifelong learning. Official Journal ofthe European Union, 30-12-2006,L394/10-L 394/18.

Faize, F. A., Husain, W., \& Nisar, F. (2017). A critical review of scientific argumentation in science education. Eurasia Journal of Mathematics, Science and Technology Education, 14(1), 475-483.

Faize, F. A., \& Akhtar, M. (2020). Addressing environmental knowledge and environmental attitude in undergraduate students through scientific argumentation. Journal of Cleaner Production, 252, 119928.

Fan, Y., Wang, T., \& Wang, K. (2020). Studying the effectiveness of an online argumentation model for improving undergraduate students' argumentation ability. Journal of Computer Assisted Learning. 36(4), 1-14.

Gagné, R. M. (1984). Learning outcomes and their effects: Useful categories of human performance. American Psychologist, 39(4), 377-385.

Giri, V \& Pailiy, M.U. (2020). Effect of Scientific Argumentation on the Development of Critical Thinking. Science \& Education. 29(1), 673-690.

Hunter, J. E., \& Schmidt, F. L. (1990). Methods of meta-analysis: Correcting error and bias in research findings. Sage Publications, Inc.

Jimenez-Aleixandre, M. P., \& Erduran, S. (2008). Argumentation in science education: 'An overview. In M. P. Jimenez-Aleixandre \& S. Erduran (Eds.),' Argumentation in science education: Perspectives from classroom-based research (pp. 47-70). Dordrecht, The Netherlands: Springer

Larrain, A., Freire, P., Grau, V., Lopez, P., Salvat, I., Silva, M., \& Gastellu, V. (2018). The effect' of peer-group argumentative dialogue on delayed gains in scientific content knowledge. In V. Grau \& D. Whitebread (Eds.), Relationships between classroom dialogue and support for metacognitive, self- regulatory development in educational contexts. New Directions for Child and Adolescent Development, 162, 1-21.

Larrain, A., Freire, P., López , P., \& Grau, V. (2019) Counter-Arguing During Curriculum-Supported Peer Interaction Facilitates Middle-School Students' Science Content Knowledge, Cognition and Instruction, 37:4, 453-482, DOI: 10.1080/07370008.2019.1627360 
Lawson, A. E. (2010). Basic inferences of scientific reasoning, argumentation, and discovery. Science Education, 94(2), 336-364.

Lipsey, M. W., \& Wilson, D. B. (2001). Practical Meta-Analysis. Sage Publictions: New Delhi.

National Research Council. (2012). A framework for K-12 science education: practices, crosscutting concepts and core ideas. Washington, DC: The National Academies Press

Norris, S., Philips, L., \& Osborne, J. (2007). Scientific inquiry: The place of interpretation and argumentation. Science as Inquiry in the Secondary Setting, 87-98.

OECD. (2013). PISA 2015 Draft science framework. Paris: OECD. Retrieved June 5, 2013 from the World Wide Web http://www.oecd.org/pisa/ pisaproducts/pisa2015draftframeworks.html

Pekel, F. O. (2019). Effectiveness of argumentation-based concept cartoons on teaching global warming, ozone layer depletion, and acid rain. Journal of Environmental Protection and Ecology 20(2), 945-953.

Ping, I. L., Halim, L., \& Osman, K. (2019). The Effects of Explicit Scientific Argumentation Instruction through Practical Work on Science Process Skills. Jurnal Penelitian dan Pembelajaran IPA. 5(2), 112-131.

Sadler, T. D., \& Zeidler, D. (2005a). The significance of content knowledge for informal reasoning regarding socioscientifi c issues: Applying genetics knowledge to genetic engineering issues. Science Education, 89(1), 71-93.

Sadler, T. D., \& Zeidler, D. L. (2005b). Patterns of informal reasoning in the context of socio-scientific decision making. Journal of Research in Science Teaching: The Official Journal of the National Association for Research in Science Teaching, 42(1), 112-138.

Sampson, V., \& Schleigh, S. (2013). Scientific Argumentation in Biology: 30 Classroom activities. USEA: National Science Teacher Association Press.

Sampson, V., \& Clark, D. (2009). The impact of collaboration on the outcomes of scientific argumentation. Science Education, 93(3), 448-484.

Tsai, C.-Y. (2018). The effect of online argumentation of socio-scientific issues on students' scientific competencies and sustainability attitudes. Computers \& Education, 116, 14-27. 